\title{
Assessment of Heavy Metals in Water and Fishes of Oyo Field and Ilaje Coastal Waters, Ondo State, Nigeria
}

\author{
Ukelina U. Undie ${ }^{1 *}$, Ishaq S. Eneji ${ }^{2}$, Muleh E. Khan ${ }^{2}$ \\ ${ }^{1}$ Standards Organisation of Nigeria, Jos 930101, Nigeria \\ ${ }^{2}$ Federal University of Agriculture, Makurdi 970101, Nigeria
}

Corresponding Author Email: kelinauu@yahoo.com

https://doi.org/10.18280/eesrj.060301

Received: 14 June 2019

Accepted: 23 August 2019

\section{Keywords:}

water quality, toxic metals, fish, AAS analysis, contamination, coastal water

\begin{abstract}
The study, aimed at assessing comparative concentration of heavy metals at the shoreline and about $70 \mathrm{~km}$ offshore, determined levels of heavy metals ( $\mathrm{Pb}, \mathrm{Cd}, \mathrm{As}, \mathrm{Cr}$ and $\mathrm{Hg}$ ) in water and Tilapia bravemanus at the shoreline of Ilaje Local Government Area of Ondo State, Nigeria (SP1) using AAS technique. Same metals were assessed in water and Euthynnus alleteratus at Oyo Oil Field, about $70 \mathrm{~km}$ offshore of Ondo State (SP2). Trends of heavy metals in water and fish at $\mathrm{SP} 1$ were $\mathrm{Hg}>\mathrm{Cd}>\mathrm{Cr}>\mathrm{As}>\mathrm{Pb}$ and $\mathrm{Hg}>\mathrm{Cd}>\mathrm{Cr}>\mathrm{As}>\mathrm{Pb}$ respectively. While trends in water and fish at $\mathrm{SP} 2$ were $\mathrm{Cr}>\mathrm{Hg}>\mathrm{Cd}>\mathrm{As}>\mathrm{Pb}$ and $\mathrm{Cr}>$ $\mathrm{Cd}>\mathrm{As}>\mathrm{Hg}>\mathrm{Pb}$ respectively. Bioaccumulation factor (BAF) in SP1 ranged from 217.43 to 1773 . In SP2 it ranged from 31.34 to 331 . Heavy metal contamination in water at SP1 was higher than at SP2. Similarly, heavy metal bioaccumulation in Tilapia brevimanus was higher than in Euthynnus alleteratus. Based on the outcome of the study, Tilapia brevimanus and Euthynnus alleteratus can be used as bio-indicators of heavy metal contamination in SP1 and $\mathrm{SP} 2$ respectively.
\end{abstract}

\section{INTRODUCTION}

Water is an essential requirement for the sustenance of life. Many studies have been conducted, and more are still being conducted, to improve sustainable management of water resources. Most of the studies are carried out to determine the level of contaminants in water and how to improve its suitability for various uses [1-2]. Increasing contamination of water bodies through anthropogenic activities is becoming a global challenge [2-4]. Toxic heavy metals are among persistent contaminants of water bodies. They are distributed in the environment through natural processes such geological weathering, atmospheric deposition or through anthropogenic activities such as agricultural, municipal and industrial discharges [5]. Once introduced into the environment, they migrate through food chain [6].

Recent threat to coastal waters is oil and gas pollution. The major activities include drilling, exploration and production, and all these activities introduce toxic metal-contaminated wastes into the environment. Produced water is the largest waste generated by the oil industry, and it contains various heavy metals, which, unlike hydrocarbons, are nonbiodegradable [7-8]. According to the Directorate of Petroleum Resources (DPR) in Nigeria, about 2, 571,113.90 barrels of crude oil were spilled on the environment between 1976 and 1988, with estimated 17.2 billion $\mathrm{m}^{3}$ of natural gas flared annually as a result of oil and gas production activities [9-11].

The fate and transport of these heavy metals often involve aquatic environment where they bio-accumulate and biomagnify, especially metals with high uptake and low elimination rates in the tissues of fish [12-13]. As the metals migrate through the food chain, they end up in humans through consumption of the aquatic organisms [14]. Although some of the heavy metals, such as, $\mathrm{Zn}, \mathrm{Cr}, \mathrm{Co}$, Mo and Fe play important physiological roles in the body of living organisms [15], others are nonessential metals, also known as xenobiotic or foreign elements, with no proven biological function. They include $\mathrm{Al}, \mathrm{Cd}, \mathrm{Hg}, \mathrm{Sn}$ and $\mathrm{Pb}[16]$.

The main factors affecting bioaccumulation of heavy metals in fish are concentration in water and period of exposure. However, environmental factors such as $\mathrm{pH}$, alkalinity, temperature, hardness, oxygen concentration and dissolved organic matter may also affect bioaccumulation and toxicity in fish [17]. In some cases, the concentrations are not high enough to pose apparent toxicological effects such as sickness or death but can be remote causes of low production, leading to population decline and eventual extinction [18].

The bioaccumulation factor (BAF), which is basically the ratio of centration of heavy metals in the body of an organism to concentration in the ambient environment, helps to determine affinity of heavy metals to tissues of the organisms, and this increases the chances of diseases. Many diseases have been associated with toxic heavy metals. Arsenic exposure has been associated with clinical conditions such as cardiovascular and peripheral vascular disease [19]. $\mathrm{Pb}$ ions have been reported to compete with essential metallic cations for binding sites, inhibiting enzyme activity, or altering the transport of essential cations such as calcium [20]. Decreases in olfactory function has been attributed to airborne cadmium particulate matter, especially in the work environment [21]. $\mathrm{Cr}$ is one of the essential heavy metals, however high concentration of it has been associated with adverse health effects. Another important factor responsible for adverse effect of $\mathrm{Cr}$ is the oxidative state. The hexavalent form $\left(\mathrm{Cr}^{+6}\right)$ has been reported as the most toxic species. Both the hexavalent and trivalent 
$\left(\mathrm{Cr}^{3+}\right)$ are considered important environmental pollutants in water sources [22]. $\mathrm{Hg}$ is one of the most toxic heavy metals because of its predisposition to methylation. Methyl mercury compounds are the most toxic mercury compounds. Dimethyl mercury has an oral $\mathrm{LD}_{50}$ of about $0.08 \mathrm{mg} / \mathrm{kg}$ for rat. An estimated exposure of $1 \mathrm{mg} / \mathrm{m}^{3}$ for 3 months has resulted in death in humans [23].

A study by Olusola and Festus [3] on Ondo coastal waters determined $\mathrm{Cr}, \mathrm{Cd}, \mathrm{Pb}, \mathrm{Cu}, \mathrm{Zn}$ and $\mathrm{Ni}$ in water, fish and sediments. Similarly, study by [6] around the same area determined $\mathrm{Pb}, \mathrm{Zn}, \mathrm{Cu}, \mathrm{Cr}$ and $\mathrm{Ni}$ in water and sediments. Both studies were restricted to the shoreline and estuary, and $\mathrm{Hg}$, a toxic pollutant in aquatic environments was not considered. And only two xenobiotic heavy metals $(\mathrm{Cd}$ and $\mathrm{Pb})$ were included in the studies. This may be due to the difficulty of analysing metals such as As and $\mathrm{Hg}$.

Heavy metals contamination of water bodies remains a global environmental challenge. Apart from the toxic effects, they are persistent pollutants that are most times only detected after causing harm to living organisms. As stated above, previous studies on heavy metals at Ondo coastal water were restricted to the estuaries and shoreline, and the levels of mercury were not considered. This study aims to assess heavy metal levels deeper offshore, and equally determine levels of mercury.

\section{MATERIALS AND METHODS}

\subsection{Study area}

Oyo Field is about $70 \mathrm{~km}$ off the coast of Ilaje Local Government Area of Ondo State, Nigeria, with a water depth of about $410 \mathrm{~m}$. It lies approximately between latitude $5^{\circ} 30^{\prime}-$ $6^{\circ} 15^{\prime} \mathrm{N}$ and longitude $3^{\circ} 50^{\prime}-4^{\circ} 35^{\prime} \mathrm{E}$. Ugbonla is a coastal town of Ilaje Local Government Area. Ilaje has a total land area of 2,300 square $\mathrm{km}$, and a population of 290,615, according to 2006 NPC census [24], and lies within $5^{\circ} 45^{\prime}$ $6^{\circ} 15^{\prime} \mathrm{N}$ and $4^{\circ} 30^{\prime}-5^{\circ} 00^{\prime}$ (Figure 1 ). The activities in the area include fishing, peasant farming, artisan trade etc. Though not directly linked to the local economy, offshore oil exploration is the main industrial activity and a potential point source pollution of the aquatic environment.

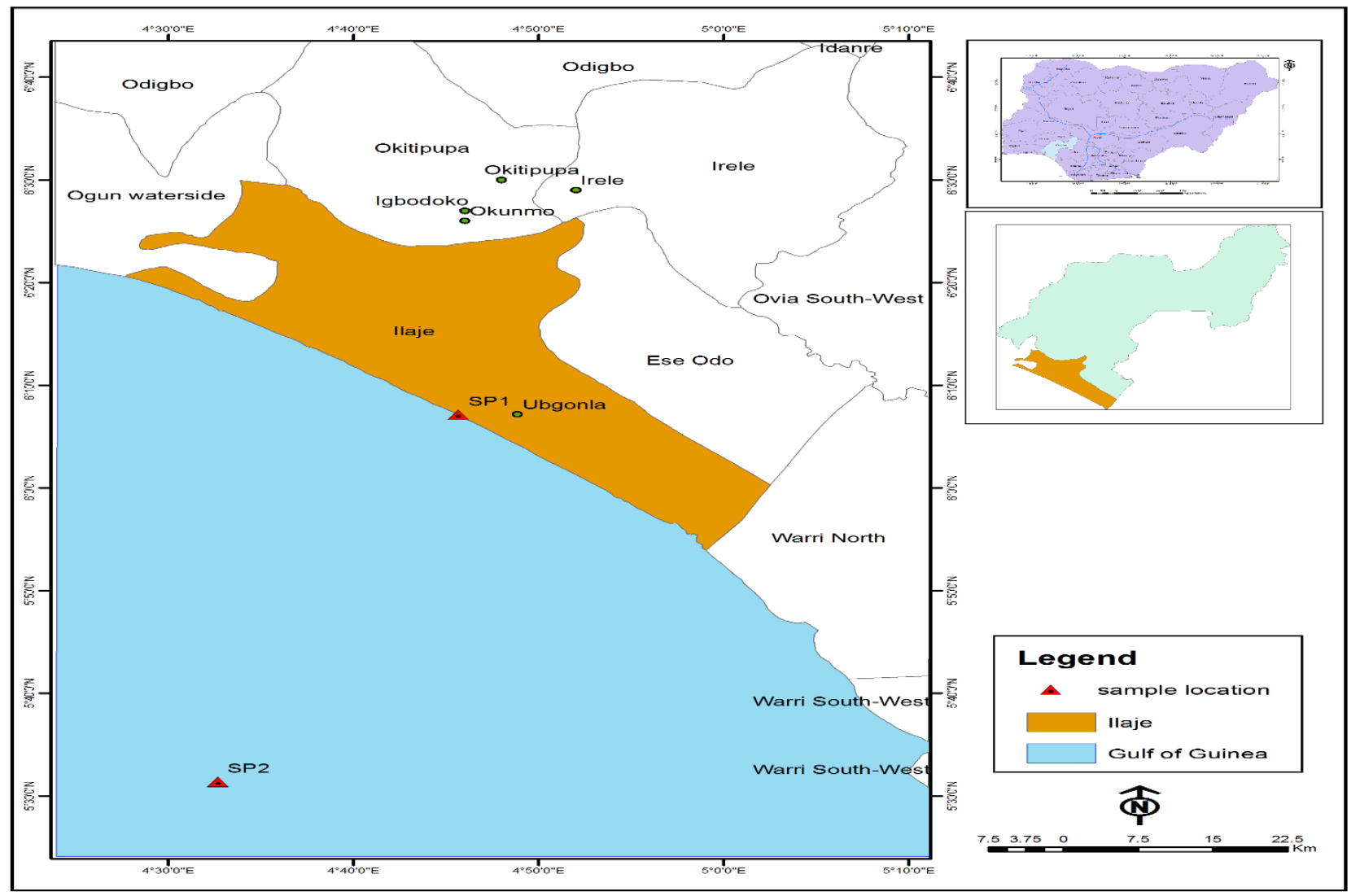

Figure 1. Map of Nigeria showing Ondo State, Ilaje LGA and sampling points

According to a survey by Olufayo, et al. [25], fishing is the commonest occupation in the study area, with $32 \%$, followed by sand dredging with $26.3 \%$, farming $15.1 \%$, boat operators $8.8 \%$, thrift collectors $8.8 \%$, civil servants $4.5 \%$, and traders $4.5 \%$. However, the survey did not consider the unemployed and the section of the population which may be involved in other sources of livelihood.

The water at both locations is used basically for fishing and navigation, which necessitates the determination of bioaccumulation.

\subsection{Sampling and sample analysis}

All glassware and porcelain were soaked in $3 \% \mathrm{HNO}_{3}$, washed 24 hours prior to use, rinsed with distilled water, ovendried and allowed to cool to room temperature. Water samples were collected with a $500 \mathrm{~mL}$ beaker at Ugbonla Sampling Point (SP1) and Oyo Field Sampling Point (SP2) between 
$10 \mathrm{~cm}$ to $30 \mathrm{~cm}$ below the water surface. At SP1 10 samples were collected at different locations along the shoreline at interval of about 100 metres covering a distance of about 1 $2 \mathrm{~km}$ and pooled into a representative sample. According to [26], samples were collected at the operational area of SP2, $500 \mathrm{~m}$ upstream and $500 \mathrm{~m}$ downstream, then pooled to make a representative sample. The water samples were acidified by addition of conc. $\mathrm{HNO}_{3}$.

All samples were stored in icebox, transported to the laboratory, stored in a refrigerator and analysed within 3 days. Exactly $100 \mathrm{~mL}$ of acidified sample was measured in a 250 $\mathrm{mL}$ conical flask and $5 \mathrm{~mL}$ of conc. $\mathrm{HNO}_{3}$ was added and covered with watch glass. The content was heated on a hot plate at $60{ }^{\circ} \mathrm{C}$ for 30 minutes and then cooled to $45^{\circ} \mathrm{C}$. The flask and watch glass were rinsed with distilled water and filtered into a clean conical flask, then the filter was rinsed with $3 \mathrm{~mL}$ distilled water. The filtrate was transferred into a $100 \mathrm{~mL}$ volumetric flask, and the conical flask rinsed with 5 $\mathrm{mL}$ distilled water into the volumetric flask. The sample was made up to $100 \mathrm{~mL}$ mark with distilled water, agitated to mix thoroughly and analysed using FS240AA Agilent Atomic Absorption Spectrometer.

At SP1, four mature samples of Tilapia brevimanus with an average length of $19 \mathrm{~cm}$ and average weight $92.4 \mathrm{~g}$ were bought from fishermen by the coast. They were stored in icebox and transported to the laboratory to retain their freshness. At SP2 two mature Euthynnus alleteratus with an average length of $34.5 \mathrm{~cm}$ and average weight of $468.2 \mathrm{~g}$ were caught with hook and line, stored in icebox filled with ice and transported onshore by helicopter. The fish were measured with measuring ruler to determine length, and weighed with a calibrated scale to determine weight. The gills, intestines and muscle were dissected and each organ was oven-dried to a constant weight at $105^{\circ} \mathrm{C}$. Each dried part was crushed with mortar and pestle to fine sizes, then stored in labelled plastic containers in a desiccator until digestion. Approximately $1 \mathrm{~g}$ of the crushed sample was weighed into a round bottom flask and $10 \mathrm{~mL}$ conc. $\mathrm{HNO}_{3}$ and $2 \mathrm{~mL} \mathrm{HClO}_{4}$ were added. After digestion at $60-65{ }^{\circ} \mathrm{C}, 50 \mathrm{~mL}$ distilled water was added and filtered. More distilled water was used to rinse the filter paper to make up to $100 \mathrm{~mL}$. The digest was stored in pre-cleaned polypropylene bottles until analysis using FS240AA Agilent Atomic Absorption Spectrometer. The standard was run for the working curves, followed by the blank to overcome instrument drift. Heavy metal analysis was carried out using FS240AA Agilent Atomic Absorption Spectrometer. The sample was thoroughly agitated and $100 \mathrm{~mL}$ transferred into a glass beaker of $250 \mathrm{~mL}$. The sample was aspirated into oxidising air/acetylene, nitrous oxide/acetylene flame. The metal concentration was read in $\mathrm{mg} / \mathrm{L}$ from the extracted standard calibration curve. The analyses were conducted in triplicate for each element and the average values were calculated.

\section{RESULTS AND DISCUSSION}

Mean concentrations of heavy metals $(\mathrm{Pb}, \mathrm{Cd}, \mathrm{As}, \mathrm{Cr}$ and $\mathrm{Hg}$ ) in SP1 and SP2 are presented in Table 1 side-by-side with NESREA limits. In Table 2 concentrations of heavy metal in organs (gills, intestine and muscle) of Tilapia brevimanus from SP1 are presented. Similarly, concentrations of heavy metals in the organs (gills, intestine and muscle) of Euthynnus alleteratus (SP2) are presented in Table 3. Concentration of heavy metals in SP1 and SP2 are presented side-by-side with concentrations in water and the bioaccumulation factor (BAF) in Table 4. Trend of Heavy Metals in Water and Fish Species is presented in Table 5. Trend of Heavy Metals in Fish Organs from SP1 and SP2 is presented in Table 6. Trend of organ accumulation of heavy metal in SP1 is presented in Table 7 and 8. Graphical presentation of the results is on Tables 2, 3 and 4.

Table 1. Mean concentration of heavy metals in SP1 water compared with NESREA limits

\begin{tabular}{cccc}
\hline Heavy metal & SP1 water $(\boldsymbol{\mu g} / \mathbf{L})$ & $\begin{array}{c}\text { SP2 water } \\
(\boldsymbol{\mu g} / \mathbf{L})\end{array}$ & $\begin{array}{c}\text { NESREA } \\
\text { limits }(\boldsymbol{\mu g} / \mathbf{L})\end{array}$ \\
\hline $\mathrm{Pb}$ & 0.18 & 0.24 & 10 \\
$\mathrm{Cd}$ & 70 & 0.48 & 5 \\
$\mathrm{As}$ & 12 & 0.32 & 50 \\
$\mathrm{Cr}$ & 18 & 0.72 & $*$ \\
$\mathrm{Hg}$ & 219 & 0.54 & 1 \\
\hline Note: ${ }^{\mathrm{Cr}}{ }^{+6}=1 \mu \mathrm{g} / \mathrm{L}, \mathrm{Cr}^{+3}=500 \mu \mathrm{g} / \mathrm{L}$ & &
\end{tabular}

Table 2. Comparative concentration of heavy metals in organs of Tilapia brevimanus (SP1)

\begin{tabular}{cccc}
\hline Heavy metal & \multicolumn{3}{c}{ Concentration $(\boldsymbol{\mu g} / \mathbf{L})$} \\
\cline { 2 - 4 } & Muscle & Gills & Intestine \\
\cline { 2 - 4 } $\mathrm{Pb}$ & 0.12 & 0.31 & 217 \\
$\mathrm{Cd}$ & 103 & 114 & 166 \\
$\mathrm{As}$ & 67 & 72 & 86 \\
$\mathrm{Cr}$ & 60 & 121 & 81 \\
$\mathrm{Hg}$ & 227 & 1264 & 282 \\
\hline
\end{tabular}

Table 3. Comparative concentration of heavy metals in organs of Euthynnus alleteratus (SP2)

\begin{tabular}{cccc}
\hline Heavy metal & \multicolumn{3}{c}{ Concentration $(\boldsymbol{\mu g} / \mathbf{L})$} \\
\cline { 2 - 4 } & Muscle & Gills & Intestine \\
\cline { 2 - 4 } $\mathrm{Pb}$ & 0.22 & 0.12 & 31 \\
$\mathrm{Cd}$ & 62 & 67 & 118 \\
$\mathrm{As}$ & 93 & 56 & 85 \\
$\mathrm{Cr}$ & 101 & 111 & 119 \\
$\mathrm{Hg}$ & 0.21 & 157 & 0.16 \\
\hline
\end{tabular}

Table 4. Bioaccumulation of heavy metals

\begin{tabular}{ccccc}
\hline $\begin{array}{c}\text { Heavy wetal } \\
(\boldsymbol{\mu g} / \mathbf{L})\end{array}$ & $\begin{array}{c}\text { SP1 } \\
\text { water }\end{array}$ & BAF & $\begin{array}{c}\text { SP2 } \\
\text { water }\end{array}$ & BAF \\
\hline $\mathrm{Pb}$ & 0.18 & 1207.94 & 0.24 & 130.58 \\
$\mathrm{Cd}$ & 70 & 5.47 & 0.48 & 514.58 \\
$\mathrm{As}$ & 12 & 18.75 & 0.32 & 731.25 \\
$\mathrm{Cr}$ & 18 & 14.56 & 0.72 & 459.72 \\
$\mathrm{Hg}$ & 219 & 8.10 & 0.54 & 291.43 \\
\hline
\end{tabular}

This study revealed higher concentrations of heavy metal at SP1, which is by the shoreline, than SP2, about $70 \mathrm{~km}$ offshore. $\mathrm{Pb}$ had the least concentration at both locations while $\mathrm{Hg}$ was highest at SP1 and Cr highest in SP2 (Table 1). The nearshore water is predisposed to contaminant from erosion of coastal rivers that empty into the sea and other anthropogenic activities around the coastal area, while the offshore receives contaminants from dry and wet precipitation, ocean currents [27]. In this study area (Oyo Oil Field) there is also a likelihood of point source contamination from oil exploration. According to [28], dilution of contaminants increases seaward from the coast because of the depth of the water. However, this can only be true in the case of SP1 and SP2 if the two areas were receiving the same quantity of contaminants. On the 
other, heavy metal contamination from oil exploitation may be lower than contamination from natural processes and anthropogenic activities at the coastal area. Concentrations at both points were within NESREA limits except for $\mathrm{Cd}$ and $\mathrm{Hg}$ at SP1. Results of previous studies in Ugbonla and around Ilaje axis revealed higher concentrations of some heavy metals than in this study. [29], working on water quality of Oil Producing Areas of Ilaje, Nigeria, reported $\mathrm{Pb} 160 \mu \mathrm{g} / \mathrm{L}, \mathrm{Cd} 20 \mu \mathrm{g} / \mathrm{L}$ and AS $1530 \mu \mathrm{g} / \mathrm{L}$ at Ugbonla. [3] reported Pb $570-790 \mu \mathrm{g} / \mathrm{L}, \mathrm{Cd}$ $80-210 \mu \mathrm{g} / \mathrm{L}, \mathrm{Cr} 310-340 \mu \mathrm{g} / \mathrm{L}$ for coastal waters of Ondo State, Nigeria. [30] reported $\mathrm{Pb} 2900-3400 \mu \mathrm{g} / \mathrm{L}, \mathrm{Cd} 3700-$ $3800 \mu \mathrm{g} / \mathrm{L}, \mathrm{Cr} 4500-6900 \mu \mathrm{g} / \mathrm{L}$. [31] reported Pb $1480-2290$ $\mu \mathrm{g} / \mathrm{L}, \mathrm{Cd} 350-480 \mu \mathrm{g} / \mathrm{L}$, As $20-40 \mu \mathrm{g} / \mathrm{L}$ and Cr $390-560$ $\mu \mathrm{g} / \mathrm{L}$.

Table 5. Trend of heavy metals in water and fish species

\begin{tabular}{cl}
\hline Water & Trend of heavy metals \\
\hline SP1Water & $\mathrm{Hg}>\mathrm{Cd}>\mathrm{Cr}>\mathrm{As}>\mathrm{Pb}$ \\
SP1 Fish & $\mathrm{Hg}>\mathrm{Cd}>\mathrm{Cr}>\mathrm{As}>\mathrm{Pb}$ \\
SP2 Water & $\mathrm{Cr}>\mathrm{Hg}>\mathrm{Cd}>\mathrm{As}>\mathrm{Pb}$ \\
SP2 Fish & $\mathrm{Cr}>\mathrm{Cd}>\mathrm{As}>\mathrm{Hg}>\mathrm{Pb}$ \\
\hline
\end{tabular}

Table 6. Trend of organ accumulation of heavy metal in SP1

\begin{tabular}{cl}
\hline Heavy metal & $\begin{array}{c}\text { Trend of accumulation in } \\
\text { organs }\end{array}$ \\
\hline $\mathrm{Pb}$ & Intestine $>$ Gills $>$ Muscle \\
$\mathrm{Cd}$ & Intestine $>$ Gills $>$ Muscle \\
$\mathrm{As}$ & Intestine $>$ Gills $>$ Muscle \\
$\mathrm{Cr}$ & Gills $>$ Intestine $>$ muscle \\
$\mathrm{Hg}$ & Gills $>$ Intestine $>$ muscle \\
\hline
\end{tabular}

Table 7. Trend of organ accumulation of heavy metal in SP2

\begin{tabular}{cl}
\hline Heavy Metal & $\begin{array}{c}\text { Trend of accumulation in } \\
\text { organs }\end{array}$ \\
\hline $\mathrm{Pb}$ & Intestine $>$ Muscle $>$ Gills \\
$\mathrm{Cd}$ & Intestine $>$ Gills $>$ Muscle \\
$\mathrm{As}$ & Muscle $>$ Intestine $>$ Gills \\
$\mathrm{Cr}$ & Intestine $>$ Gills $>$ Muscle \\
$\mathrm{Hg}$ & Gills $>$ Muscle $>$ Intestine \\
\hline
\end{tabular}

Table 8. Trend of heavy metals in fish organs from SP1 and SP2

\begin{tabular}{ccc}
\hline Fish organ & Trend of heavy metals & General Trend \\
\hline SP1 Muscle & $\mathrm{Hg}>\mathrm{Cd}>\mathrm{As}>\mathrm{Cr}>\mathrm{Pb}$ & \\
SP1 Gill & $\mathrm{Hg}>\mathrm{Cr}>\mathrm{Cd}>\mathrm{As}>\mathrm{Pb}$ & $\mathrm{Hg}>\mathrm{Cd}>\mathrm{AS}>\mathrm{Cr}>\mathrm{Pb}$ \\
SP1 Intestine & $\mathrm{Hg}>\mathrm{Pb}>\mathrm{Cd}>\mathrm{As}>\mathrm{C}$ & \\
SP2 Muscle & $\mathrm{I} \mathrm{Cr}>\mathrm{As}>\mathrm{Cd}>\mathrm{Pb}>$ \\
& $\mathrm{Hg}$ & \\
SP2 Gill & $\mathrm{Hg}>\mathrm{Cr}>\mathrm{Cd}>\mathrm{As}>\mathrm{Pb}$ & $\mathrm{Cr}>\mathrm{Cd}>\mathrm{AS}>\mathrm{Hg}>\mathrm{Pb}$ \\
SP2 Intestine & $\mathrm{Cr}>\mathrm{Cd}>\mathrm{As}>\mathrm{Pb}>\mathrm{Hg}$ & \\
\hline
\end{tabular}

Different organs of Tilapia brevimanus and Euthynnus alleteratus species exhibited varying levels of heavy metals bioaccumulation (Tables 2, 3 and 4). $\mathrm{Hg}(1264 \mu \mathrm{g} / \mathrm{kg}$ ) was the highest concentration of heavy metal in the gills of Tilapia brevimanus while $\mathrm{Pb}(0.12 \mu \mathrm{g} / \mathrm{kg})$ was the least, in the muscle. In SP1 gills had $54.39 \%$ of total heavy metal load, intestine $29.09 \%$ and muscle $15.98 \%$. Heavy metals distribution in SP1 was as follows: $\mathrm{Pb}$ (intestine $99.80 \%$, gills $0.14 \%$, muscle $0.06 \%$ ), Cd (intestine $43.34 \%, 29.77 \%$, muscle $26.89 \%$ ), AS (intestine $38.22 \%$, gills $32 \%$, muscle $29.78 \%$ ), $\mathrm{Cr}$ (gills $46.18 \%$, intestine $30.92 \%$, muscle $22.90 \%$ ), $\mathrm{Hg}$ (gills $71.29 \%$, intestine $15.91 \%$, muscle $12.80 \%$ ). In SP2 Cr was the most concentrated heavy metal in Euthynnus alleteratus, and the intestine of the fish had the highest concentration, while $\mathrm{Pb}$ was the least concentrated, with gills showing the least concentration (Figure 4). Gills had $39.08 \%$, intestine $35.29 \%$ and muscle $25.63 \%$ of the heavy metal load.

Heavy metals distribution in SP2 was as follows: $\mathrm{Pb}$ (intestine $98.92 \%$, muscle $0.70 \%$, gills $0.38 \%$ ), Cd (intestine $47.77 \%$, gills $27.13 \%$, $25.10 \%$ ), As (muscle $39.74 \%$, intestine $36.33 \%$, gills 23.93), Cr (intestine $35.95 \%$, gills $33.54 \%$, muscle $30.51 \%$ ), $\mathrm{Hg}$ (gills $99.76 \%$, muscle $0.14 \%$, intestine $0.10 \%$ ). At both locations $\mathrm{Pb}$ and $\mathrm{Cd}$ were concentrated in the intestine while $\mathrm{Hg}$ was most in the gills.

Concentration of $\mathrm{Hg}$ in the gills and $\mathrm{Pb}$ in the intestine of both fishes suggests feeding habit may be a factor in the bioaccumulation. $\mathrm{Hg}$, which turned out to have the highest concentrations in both water and fish at the SP1, was not determined in the previous studies of Ondo coastal waters reviewed in the course of this research. This may be due to the difficulty of getting an AAS machine capable of determining $\mathrm{Hg}$ conc. [30] reported heavy metal presence in the organs of Oreochromis niloticus, Synodonthis sp., and Clarias gariepinus, so did [3] in the organs of Pentanemus

quinquarius, Pseudoltolithus senegalensis, Trichirus lepturus, Plectorhynchus meditarraneus and Seudotolithus typus, indicating a history of accumulation of heavy metals in the body tissues of biota of the coastal waters of Ondo State. However, samples for these studies were drawn only at the shoreline. In this study samples were also drawn at about 70 $\mathrm{km}$ offshore where water depth is about 400 meters. This gives an idea of comparative concentration of heavy metals in water and biota at the shoreline and $70 \mathrm{~km}$ offshore.

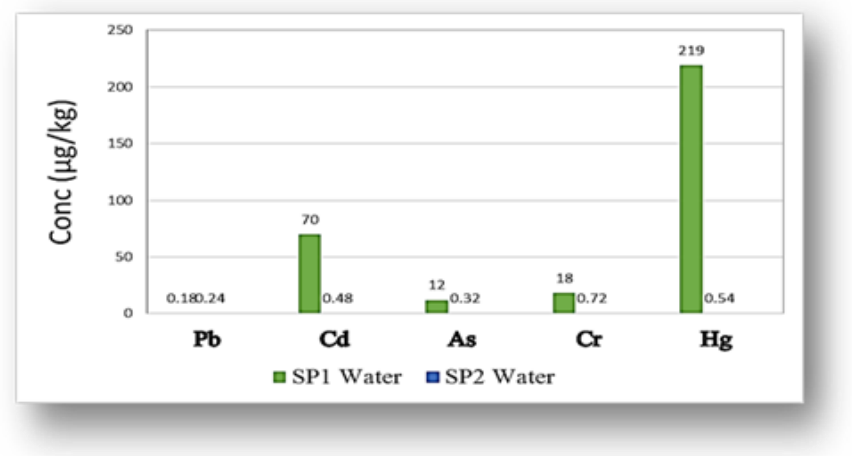

Figure 2. Comparative Concentration of Heavy Metals in SP1 Water and SP2 Water

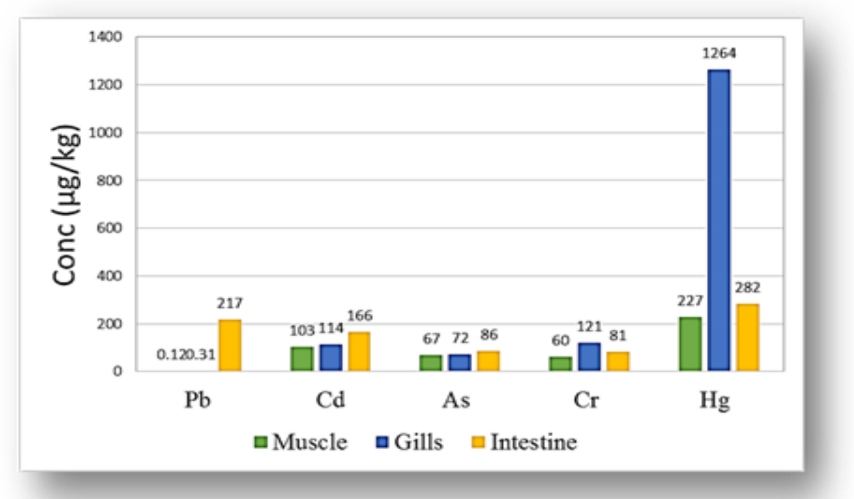

Figure 3. Comparative Concentration of heavy metals in muscle, gills and intestine of Tilapia brevimanus (SP1) 


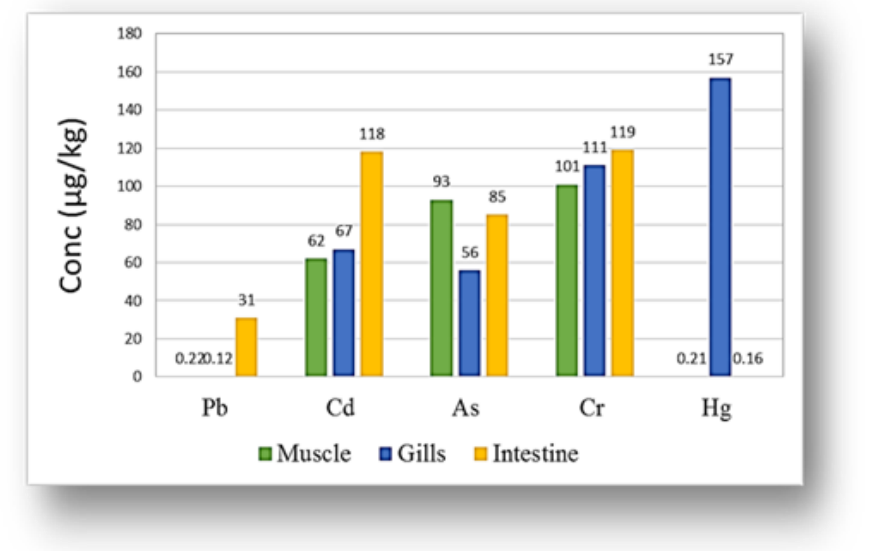

Figure 4. Comparative Concentration of heavy metals in muscle, gills and intestine of Euthynnus alleteratus (SP2)

\section{CONCLUSION AND RECOMMENDATIONS}

The concentration of heavy metals at the shoreline was higher than at Oyo Field, about $70 \mathrm{~km}$ from the shoreline, with corresponding higher concentrations in Tilapia brevimanus than in Euthynnus alleteratus. This suggests that the pollution may be from anthropogenic activities onshore.

Higher concentration of heavy metals in SP1 water may be a contributory factor to higher concentration in Tilapia brevimanus. Feeding habit may be another factor. Concentration of heavy metals in the fish tissues showed that there was bioaccumulation of the heavy metals. In both locations there was higher concentration of heavy metals in the gills and intestines than in the muscles of the fishes; this may be attributed to the difference in physiological roles in fish metabolism played by the three organs. High concentration of $\mathrm{Hg}$ in the gills of Tilapia brevimanus may be an indication of active contamination along the coastal. The novelty of this study is in two findings: heavy metal levels were lower deeper offshore (about $70 \mathrm{~km}$ from the shoreline) than at the shoreline, and $\mathrm{Hg}$, which had never been determined was the most concentrated at the shoreline.

Further studies are needed to determine the wider level of heavy metal contamination. These should include sediments and other relevant biota, covering all the seasons, to ascertain a more holistic pollution status of the water, and give a better basis for comparison of heavy metal load of the two locations considered in this study.

This study therefore concludes that heavy metal contamination at the shoreline is higher than 70 kilometres offshore, and Tilapia brevimanus and Euthynnus alleteratus are good bio-indicators for monitoring heavy metal contamination.

\section{ACKNOWLEDGMENT}

The authors are grateful to Springboard Laboratory, Awka, Kofa Services, Jos, National Metallurgical Development Centre, Jos, Grand Cereals Limited, Jos, Nigeria, and all those whose facilities were used for sampling and sample preparation. The authors are equally grateful to prospective peer reviewers and editors.

\section{REFERENCES}

[1] Eneji, S.I., Sha'Ato, R., Annune, A. (2012). An Assessment of of heavy metals loading in River Benue in Makurdi Metropolitan Area in Central Nigeria. Environmental Monitoring and Assessment, 184(1): 201-207. https://doi.org/10.1007/s10661-011-1959-0

[2] Bolarinwa, J.B., Fasakin, E.A., Fagbenro, A.O. (2016). Physicochemical analysis of the coastal waters of Ondo State, Nigeria, International Journal of Research in Agriculture and Forestry, 3(11): 13-20.

[3] Olusola, J.O., Festus, A.A. (2015). Assessment of heavy metals in some Marine fish species relevant to their concentration in water and sediment from coastal waters of Ondo State, Nigeria. Journal of Marine Science: Research \& Development, 5: 163-172. https://doi.org/10.4172/2155-9910.1000163

[4] Bazzi, A.O. (2014). Heavy metals in seawater, sediments and marine organisms in the Gulf of Chabahar, Oman Sea. Journal of Oceanography and Marine Science, 5(3): 20-29. https://doi.org/10.5897/JOMS2014.0110

[5] Bauvais, C., Zirah, S., Piette, L., Chaspoul, F., Coulon, I.D. (2015). Sponging metals: Bacteria associated with the Marine sponge (Spongia officibalis) Mar. Environ. Res, 104:

20-30.

https://doi.org/10.1016/j.marenvres.2014.12.005

[6] Adesina, R.B., Ogunseiju, P. (2017). An assessment of bathymetry, hydrochemistry and trace metals in sediments of Awoye Estuary in Ilaje Area, Southwestern Nigeria. Journal of Geosciences and Geomatics, 5(2): 7886. https://doi.org/10.12691/jgg-5-2-4

[7] Pichtel, J. (2016). Oil and gas production wastewater: Soil contamination and pollution prevention. Applied and Environmental Soil Science, 216: 24. http://dx.doi.org/10.1155/2016/2707989

[8] Malik, N., Biswas, A.K., Qureshi, T.A., Borana, K., Virha, R. (2010). Bioaccumulation of heavy metals in fish tissues of a freshwater lake of Bhopal. Environmental Monitoring and Assessment, 160: 267276. https://doi.org/10.1007/s10661-008-0693-8

[9] Ajugwo, A.O. (2013). Negative effects of gas flaring: The Nigerian experience. Journal of Environmental Pollution and Human Health, 1(1): 6-8. https://doi.org/10.12691/jephh-1-1-2

[10] Ubani, E.C., Onyejekwe, I.M. (2013). Environmental impact analysis of gas flaring in the Niger Delta of Nigeria. American Journal of Science and Industrial Research, 4(4): 246-252. https://doi.org/10.5251/ajsir.2013.4.2.246.252

[11] Onyema, H.K., Iwuanyanwu, J.O., Emeghara, G.C. (2015). Evaluation of some physicochemical properties and heavy metals in post-treated produced water from offshore locations in the Niger Delta Area. Journal of Applied Sciences Environ. Management, 19(4): 767-770. https://doi.org/10.4314/jasem.v19i4.25

[12] Idriss, A.A., Ahmad, A.K. (2015). Heavy metals concentrations in fishes from Juru River, estimation of the health risk. Bull. Environ. Contam. Toxicol, 94(2): 204-208. https://doi.org/10.1007/s00128-014-1452-x

[13] Polat, F., Akin, S., Yildirim, A., Dal, T. (2015). The effect of point pollutants-originated heavy metal (lead, copper, iron and cadmium) on fish living in Yesilirmak River, Turkey, Toxicol. Ind. Health, 12: 3-12. https://doi.org/10.1177/0748233714565709 
[14] Agah, H., Leermakers, M., Elskens, M., Fatemi, S.M.R., Baeyens, W. (2009). Accumulation of trace metals in the muscles and liver tissues of five fish species from the Persian Gulf. Environmental Monitoring Assessment. 157: 499-514. https://doi.org/10.1007/s10661-008-05518

[15] Sfakianakis, D.G., Reneiri, E., Kentouri, M., Tsatsakis, A.M. (2015). Effect of heavy metals on fish larvae deformities, Enviro. Res, 137: 246-255. https://doi.org/10.1016j.envres.2014.12.014

[16] Abadi, D.R.V., Dobaradaran, S., Nabipour, I., Lamani, X., Ravanipour, M. (2015). Comparative investigation of heavy metal, trace and macro element contents in commercially valuable fish species harvested off from the Persian Gulf, Environ. Sci. Pottut. Res, 167: 511-515. https://doi.org/10.1007/s11356-014-3852-1

[17] Sassi. A., Annabi, A., Kessabi, K., Kerkeni, A., Said, K. (2010). Influence of high temperature on cadmiuminduced skeletal deformities in juvenile mosquitofish (Gambusia affinis), Fish Physio. Biochem, 36: 403-409. https://doi.org/10.1007/s10695-009-9307-9

[18] Ebrahimi, M., Taherianfard, M. (2011). The effects of heavy metals exposure on reproductive system of cyprinid fish from Kor River. Iranian Journal of Fisheries Sciences, 10: 13-24. https://doi.org/10.1088/0253$6102 / 57 / 4 / 21$

[19] Tchounwou, P.B., Patlolla, A.K., Centeno, J.A. (2003). Carcinogenic and systemic health effects associated with arsenic exposure - a critical review. Toxicol Pathol, 31(6): $\quad$ 575-588 https://doi.org/10.1080/01926230390242007

[20] Flora, S.J.S., Saxena, G., Gautam, P., Kaur, P., Gill, K.D. (2007). Lead induced oxidative stress and alterations in biogenic amines in different rat brain regions and their response to combined administration of DMSA and MiADMSA. J. Chem Biol Interac, 170: 209-220. https://doi.org/10.1016/j.cbi.2007.08.003

[21] Mascagni, P., Consonni, D., Bregante, G., Chiappino, G., Toffoletto, F. (2003). Olfactory function in workers exposed to moderate airborne cadmium levels. Neurotoxicol, 24: 717-724. https://doi.org/10.1016/S0161-813X(03)00024-X

[22] Zhitkovich, A. (2011). Chromium in drinking water: Sources, metabolism, and cancer risks. Chem Res Toxicol, 24: 1617-1629. https://doi.org/10.1021/tx200251t

[23] ATSDR. (2015). Toxic Substances Portal - Mercury and Your Health. Retrieved from https://www.atsdr.cdc.gov/mercury/index.html

[24] NBS. (2013). National Core Welfare Indicators Survey, 2006, National Bureau of Statistics. Retrieved from https://www.nigerianstat.gov.ng/nada/index.php/catalog 130

[25] Olufayo, O., Omole, F.L., Lawanson, T. (2013). Utilizing creeks for integrated rural coastal development of Ilaje Area of Nigeria. Ethiopian Journal of Environmental Studies and Management, 6(3): 294-299. https://doi.org/10.4314/ejesm.v6i3.10

[26] EGASPIN. (2002). Environmental Guidelines and Standards for the Petroleum Industry in Nigeria. 2nd edition, Department of Petroleum Resources, Lagos, Nigeria, 415-415.

[27] NOAA. (2018). National Centres for Environmental Information. Water Temperature Table of the Central Atlantic Coast. Retrieved from https://www.nodc.noaa.gov/dsdt/cwtg/catl.html.28.06 2018.

[28] Neff, J.M., Kenneth, L., Elizabeth, M.D. (2011). Produced water: Overview of composition, fates and effects. In: Kenneth L. and Neff J. (eds). Produced Water - Environmental Risks and Advances in Mitigation Technologies, New York, Springer, 3-56.

[29] Abdus-Salam, N., Adekola, F.A., Apata, A.O. (2010). A physicochemical assessment of water quality of oil producing areas of Ilaje, Nigeria. Advances in Natural and Applied Sciences, 4(3): 333-344.

[30] Asaolu, S.S., Olaofe, O. (2005). Biomagnification of some heavy and essential metals in sediments, fishes and crayfish from Ondo State coastal region, Nigeria. Pak. J. Sci. Ind, 48(2): 96-102.

[31] Adebowale, K.O., Agunbiade, F.O., Olu-Owolabi, B.I. (2009). Trace metals concentration, site variations and partitioning pattern in water and bottom sediments from coastal Area: A case study of Ondo Coast, Nigeria. Environmental Research Journal, 3(2): 46-59.

\section{NOMENCLATURE}

\begin{tabular}{|c|c|}
\hline ATSDR & $\begin{array}{l}\text { Agency for Toxic Substances and Disease } \\
\text { Registry }\end{array}$ \\
\hline BAF & Bioaccumulation Factor \\
\hline DPR & Department of Petroleum Resources \\
\hline EGASPIN & $\begin{array}{l}\text { Environmental Guidelines and Standards for the } \\
\text { Petroleum Industry in Nigeria }\end{array}$ \\
\hline $\mathrm{LD}_{50}$ & Lethal Dose \\
\hline NBS & National Bureau of Statistics \\
\hline NESREA & $\begin{array}{l}\text { National Environmental Standards } \\
\text { Regulation Enforcement Agency }\end{array}$ \\
\hline NOAA & $\begin{array}{l}\text { National Oceanic and Atmospheric } \\
\text { Administration }\end{array}$ \\
\hline $\mathrm{PC}$ & National Population Commission \\
\hline & Sampling Point 1 \\
\hline & Sampling Point 2 \\
\hline
\end{tabular}

\section{Greek symbol}

$\mu$

Microgram, $\mu / \mathrm{L}$ 